\title{
Circular Economy in Poland: Main Achievements and Future Prospects
}

\author{
Anna Avdiushchenko
}

\begin{abstract}
Circular economy (CE) is a new development strategy adopted by the European Union (EU) authorities in 2014, aiming to boost global competitiveness, foster sustainable economic growth, and generate new jobs. The CE approach maintains the added value in products for as long as possible and eliminates waste; moreover, it implies totally systemic change and innovation not only in technologies, but also in organization, society, finance methods, and policies. Such an approach leads to a new model of production and consumption and a new relationship between stakeholders at the local, regional, national, and EU levels. The first consideration of CE priorities in Poland started in 2016 when the Inter-ministerial Committee for Circular Economy was established. Representatives from nine ministries became committee members, and the chief document they prepared was the Roadmap for Circular Economy Transition. The document proposed an action plan for CE implementation and focused on increasing resource efficiency and waste reduction in Poland. Prepared with the active involvement of all possible stakeholders-businesses, NGOs, the academic and research community, and local and regional authorities - the Roadmap can be seen as a quick and effective guide. In addition to national government initiatives, there were numerous attempts to implement CE principles at the local and regional levels. The main goal of the current research was to examine the effectiveness of such national, regional, local, and business CE projects for influencing Poland's CE transition during the past three years. This study reviews the main policy documents, reports, and expertise of national, international, regional, and local organizations and NGOs involved with CE in Poland. The research is also supported by a review of the relevant academic literature. As a result, it was possible to estimate the current level of achievement, as well as future prospects for $\mathrm{CE}$ in Poland. Moreover, this research identifies potential opportunities for updating existing planning policies and tools related to CE-based development in Poland.
\end{abstract}

\footnotetext{
A. Avdiushchenko ( $\square)$

AGH University of Science and Technology, Gramatyka 10, 30-067 Krakow, Poland

e-mail: anna.avdiushchenko@gmail.com; anna.avdiushchenko@uj.edu.pl
}

Jagiellonian University in Krakow, Gronostajowa 7, 30-387 Krakow, Poland

(C) The Author(s) 2021

A. Bisello et al. (eds.), Smart and Sustainable Planning for Cities and Regions,

Green Energy and Technology, https://doi.org/10.1007/978-3-030-57764-3_10 
Keywords Circular economy $\cdot$ Roadmap $\cdot$ Local and regional initiatives • Transition process

\section{Introduction}

According to the European Commission, the circular economy (CE) is an economic model based inter alia on sharing, leasing, reusing, repairing, refurbishing, and recycling in an (almost) closed loop that aims at retaining the highest utility and value of products, components, and materials over time (Commission of European Communities, Communication No. 398, 2014). In the last few years, numerous researchers have endeavored to define and apply the main concepts of the CE approach in business and public administration strategies for sustainable development. However, the $\mathrm{CE}$ model often has differing meanings among the various stakeholders involved in this transition. That is why the $\mathrm{CE}$ approach has recently become a popular topic of academic discussion from the perspective of engineering, natural, and social sciences (Schulz et al. 2019). Moreover, CE has gained popularity as a core idea for development strategies at the national, regional, and municipal government levels (Alaerts et al. 2019).

There are numerous examples of national CE strategies, roadmaps, and action plans in EU countries, including a circular economy in the Netherlands by 2050 [10]; Finland's National Circular Economy Roadmap (Sitra 2016); ProgRess IIGerman Resource Efficiency Programme (Federal Ministry for the Environment, Nature Conservation, Building, and Nuclear Safety 2016); leading the transition: a circular economy action plan for Portugal (Ministry of Environment 2017); Towards a Model of Circular Economy for Italy-Overview and Strategic Framework (Ministry for the Environment, Land and Sea Ministry of Economic Development 2017); France Unveils Circular Economy Roadmap (The French Ministry of Ecological and Solidarity Transition 2018); Roadmap towards the Circular Economy in Slovenia (Circular Change and other consortia of partners 2018).

At the same time, a few initiatives were introduced at the regional and local levels, such as Promoting Green and Circular Economy in Catalonia: Strategy of the Government of Catalonia (Government of Catalonia 2015); Brussels RegionProgramme Régional en Economie Circulaire (2016); Scotland-Making Things Last: A Circular Economy Strategy for Scotland (The Scottish Government 2016); Circular Amsterdam (City government of Amsterdam 2016); White Paper on the Circular Economy of Greater Paris (City government of Paris 2016); Extremadura 2030: Strategy for a Green and Circular Economy (Regional government of Extremadura 2017); London's Circular Economy Route Map (London Waste and Recycling Board 2017); and the Circular Flanders kick-off statement (Vlaanderen Circulair 2017).

The first steps toward CE implementation in Poland were made at the end of 2015. During the public consultation titled Closing the Loop-An EU Action Plan 
for the Circular Economy with EU Member States, Poland presented its main national priorities for CE transition as follows:

- innovation, strengthening cooperation between industry and the scientific community, and effective implementation of innovative solutions in the economy

- the creation of a European market for secondary raw materials and facilitating their flows

- ensuring the high quality of secondary raw materials through sustainable production and consumption

- development of the services sector.

From 2016-2019, the Polish CE approach was developed and supported by numerous activities of governmental and non-governmental organizations, businesses, and research and educational institutions. The main goal of the current research was to determine the effectiveness of such $\mathrm{CE}$ initiatives in Poland at achieving CE model transition during the past three years. The findings of this research also made it possible to estimate the future prospects for CE in Poland.

\section{Concept and Method of Research}

This research examined the main policy documents, reports, and expertise of national, international, regional, and local organizations (including governmental, non-governmental, and business) addressing CE in Poland. The research was also supported by a review of the academic literature on the subject. In the final stage of the analysis, the main achievements and future directions for research were identified. The concept for the current research is presented in Fig. 1.

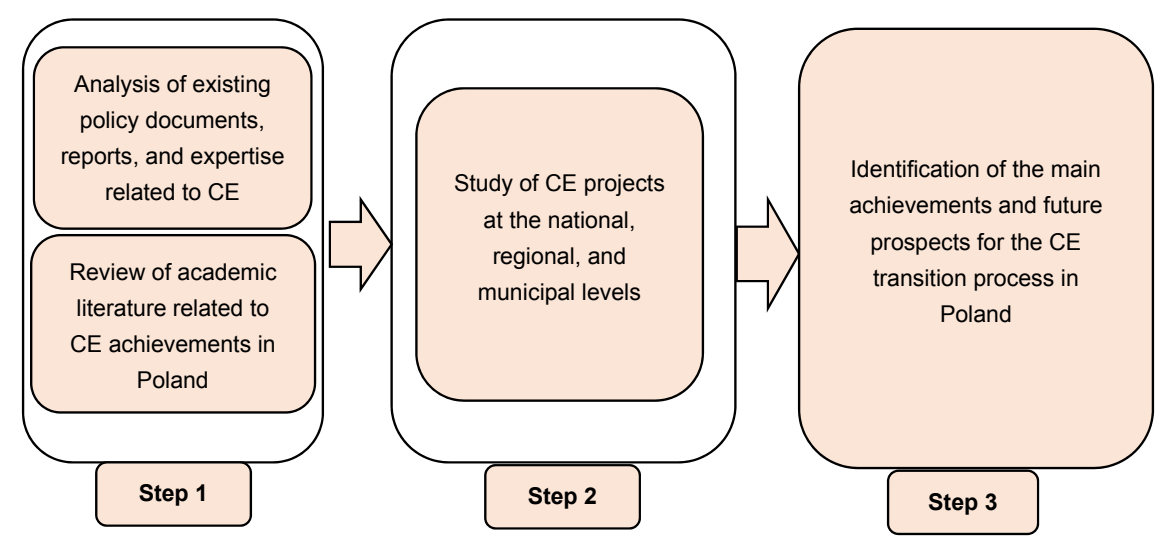

Fig. 1 Concept for investigation of CE in Poland from 2016-2019 


\section{CE Development in Poland}

The first work on CE Roadmap priorities in Poland started at the beginning of 2016. The Inter-ministerial Committee for Circular Economy was established in June 2016. Representatives from nine ministries became committee members, drawn from the Ministry of Entrepreneurship and Technology; Ministry of Environment; Ministry of National Education; Ministry of Energy; Ministry of Infrastructure and Construction; Ministry of Science and Higher Education; Ministry of Family, Labour, and Social Policy; Ministry of Agriculture and Rural Development; and Ministry of Health (Order No. 33 of the Minister of Development 2016). The Ministry of Entrepreneurship and Technology was the main state body responsible for the organizational issues and effectiveness of the inter-ministerial committee's work.

The composition of the committee shows the strategic importance and interdisciplinary nature of the circular economy concept in Poland. The Committee worked to define the strengths, weaknesses, opportunities, and threats of transition toward a CE model in Poland, expressing opinions regarding European Union initiatives for transition to CE, developing an action plan for the implementation of a circular economy in Poland specifying, in particular, the objectives and priorities of the actions along with their time horizons and the institutions responsible for their implementation, and lastly monitoring of $\mathrm{CE}$ action-plan implementation. The main document prepared by the committee was the Roadmap for Circular Economy Transition, the first draft of which was presented in December 2016. Its main goal was the preparation of an action plan for increasing resource efficiency and waste reduction in Poland. Four main avenues were proposed as follows: (I) Sustainable industrial production; (II) Sustainable consumption; (III) Bioeconomy; and (IV) New business models.

Further work on finalization of the Roadmap for Circular Economy Transition was prepared with the active involvement of all possible stakeholders (Fig. 2).

The CE concept has a broadly interdisciplinary character and covers not only changes in technological processes but also implementation of the extended responsibility of producers in the whole value chain. This demands a paradigm shift in consumption, establishing new patterns of production and consumption to create in Poland a CE society. That is why the business sector, NGOs, the academic and research community, and local and regional authorities were invited to work together on developing the roadmap for fast and effective transition to CE.

Four thematic working groups were created, taking into account key priority areas proposed in the Draft Roadmap-waste, bioeconomy, business models, and promotional and educational activities. As a result of intensive interdisciplinary and intersectoral work, the final version of the roadmap was presented at the end of 2018 and adopted in September 2019 (Roadmap 2019). More than 200 partner organizations participated in its preparation.

The roadmap includes a set of legislative, analytical, conceptual, informational, and promotional coordination tools for the main avenues identified. Moreover, as a result of the committee's work, the process of implementation, monitoring, and funding for $\mathrm{CE}$ actions was added to the CE Roadmap. 


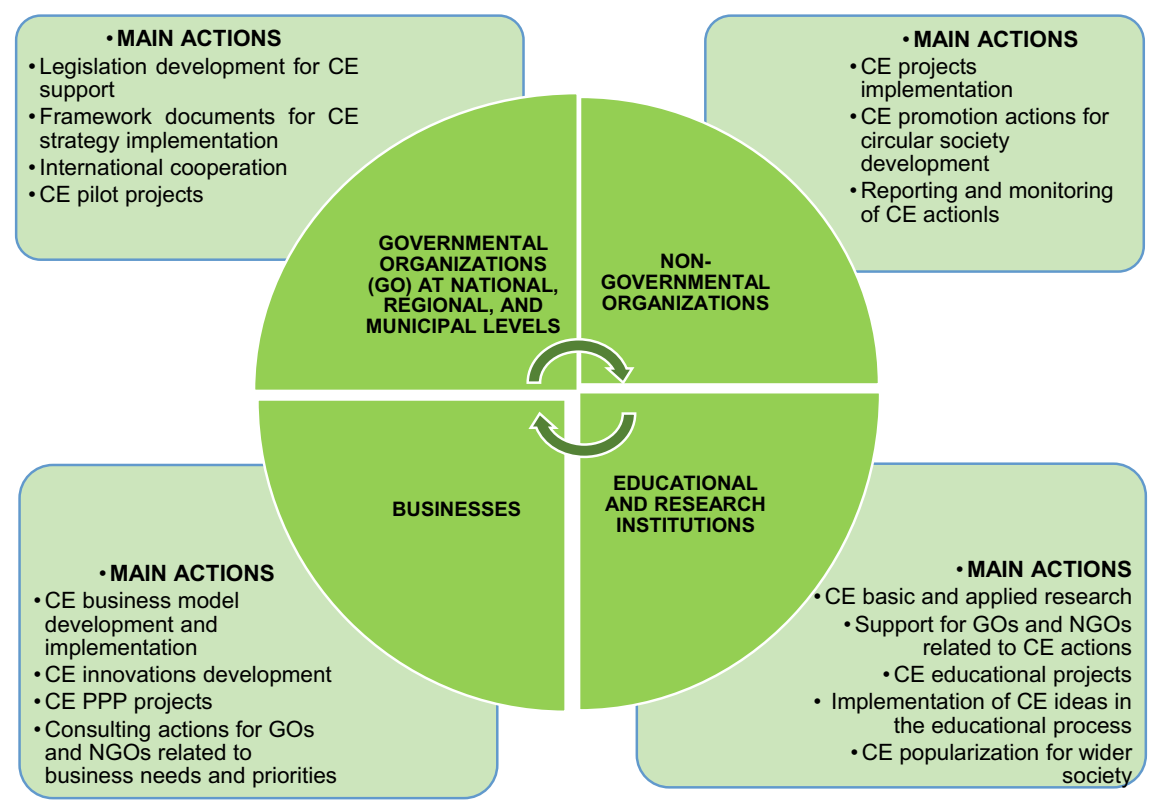

Fig. 2 Main stakeholders of CE transition process in Poland

The Roadmap for Circular Economy Transition is also one of the elements of successful realization of the Poland Strategy for Responsible Development for 2020 (with the perspective to 2030), where the Strategy of Transformation to Circular Economy was mentioned as one of the strategic projects (Poland Strategy for Responsible Development for 2020, 2019) (Fig. 3).

Another Polish national-level document that has already accounted for the recommendations and assumptions of "Towards a circular economy: A zero waste programme for Europe" (Commission of European Communities, Communication No. 398, 2014) and Closing the Loop_-An EU Action Plan for the Circular Economy (Commission of European Communities, Communication No. 614, 2015) is the updated National Plan of Waste Management 2022 adopted by the Council of Ministers of Poland in July 2016 (Resolution No. 88 of the Council of Ministers 2016). The document set new waste management targets to be met and the possible means by which this could be achieved, taking into account a nationwide CE-supportive environment.

One of the most fundamental reports examining the Polish path to $\mathrm{CE}$ was prepared as part of a research project conducted at the Institute of CE in Poland (Bachorz 2017). The research was focused on raw materials policy, design, production and distribution, consumption, recycling, and residual waste, and on the economic and social system and its readiness for CE transformation. The authors of the report made detailed analyses of the most important aspects for CE, supported by individual, indepth interviews with representatives of the academia and industrial R\&D. That 


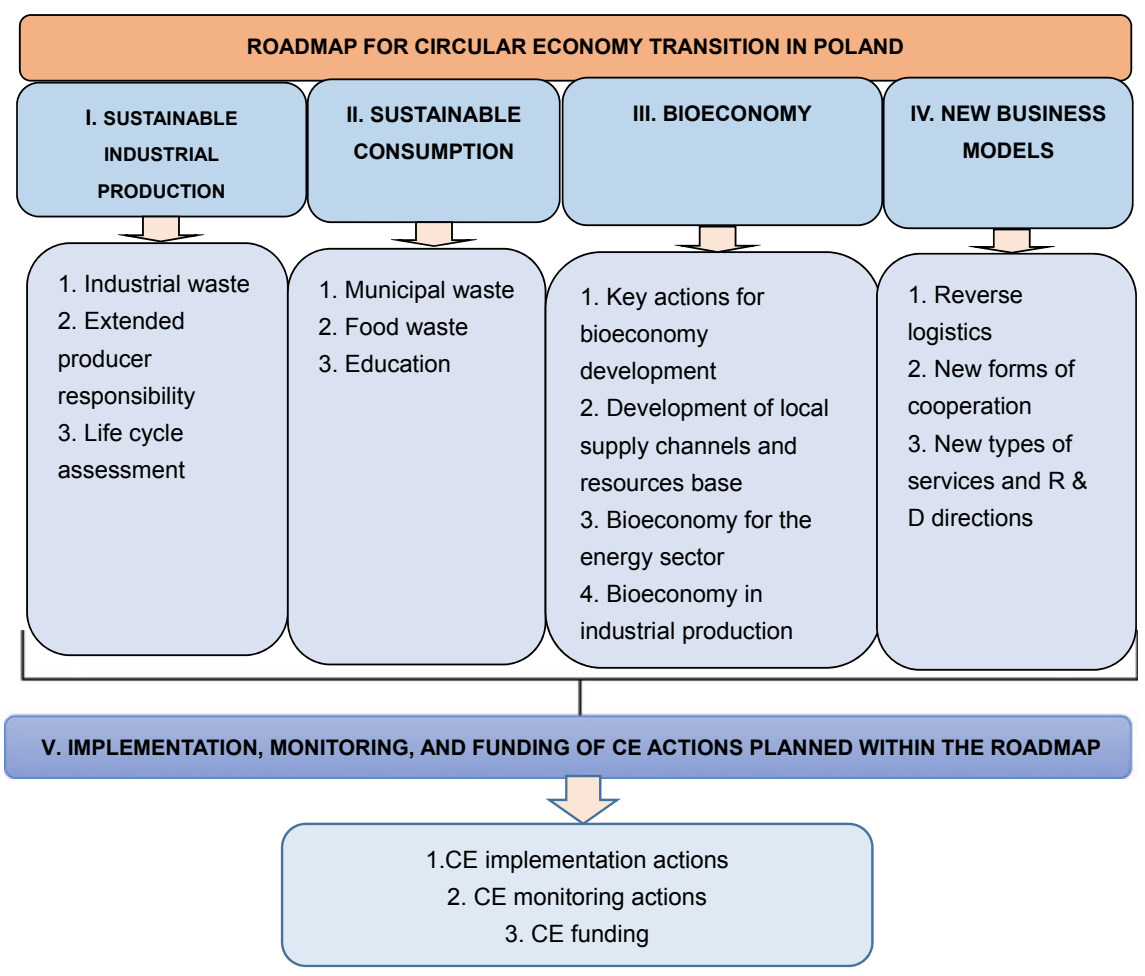

Fig. 3 Poland's roadmap for circular economy transition

analysis led to recommendations for the development of a CE action plan. Some of the recommendations were even used in the development of the CE Roadmap for Poland.

One additional report was focused on CE in Poland, prepared by the Deloitte company with the cooperation and support of the Ministry of Entrepreneurship and Technology, Ministry of Environment, and Ministry of Investment and Economic Development. The report presented possible ways of boosting CE development from a business and consumer perspective, as well as possible supporting actions on the side of the public administration (Deloitte 2018).

Recently, CE issues in Poland have become a mainstream topic of research (Baran et al. 2016; Smol et al. 2018; Woźniak and Pactwa 2018; Woźniak and Twardowski 2018; Seroka-Stolka and Ociepa-Kubicka 2019). The results obtained are helpful for understanding Polish realities and opportunities for successful CE transformation. Moreover, such research has identified numerous challenges associated with the transformation process. 


\section{CE-Related Projects}

In addition to CE-related documents and initiatives at the conceptual level, there are numerous practical projects and initiatives led by local and regional authorities, the business sector, research and educational institutions, NGOs, and intersectoral coalitions working on effective implementation of CE ideas. Only a reasonable combination of conceptual and practical $\mathrm{CE}$ approaches can yield tangible results for the Polish economy and social transformation. The following section of the research will present examples of CE-related projects in Poland in 2016-2019.

\subsection{Pilot CE Project in Polish Municipalities}

One more national level initiative related to $\mathrm{CE}$ transition is a planned CE pilot project for five rural and urban-rural municipalities in Poland, though only three of them ultimately confirmed participation: Łukowica (Kraków Province), Tuczno (Szczecin Province), and Wieluń (Łódź Province).

The main purpose of the project was to develop good practices for circulareconomy implementation at the local level, with special focus on non-urbanized areas. This pilot project is coordinated by the Ministry of Environment and financed by the National Fund of Environmental Protection and Water Management.

Municipalities, as well as business owners and individuals operating within a given municipality, could apply for as much as 45 million złoty in non-refundable grants or preferential loans to be used for investment projects involving the following (Appendix 1 to Resolution of the Management Board of National Fund of Environment Protection and Water Management, May 2017; Deloitte 2018):

1. systems for separate collection and prevention of municipal waste

2. local waste-recycling facilities

3. development of infrastructure supporting waste prevention

4. environmentally friendly transport, with a focus on public transport

5. energy efficiency (with respect to heat or electricity)

6. circular economy in households

7. circular economy in agriculture or agricultural product processing

8. saving water as a resource in households, municipalities, and businesses

9. resource-efficient economy in local business, with a focus on:

- reducing per-unit consumption of primary raw materials, including water, in manufacturing processes

- reducing per-unit waste generation in manufacturing processes

10. rational management of land by reversal of anthropogenic land degradation or finding new uses for land degraded by human activities. 
Among the participating municipalities, Wielun stands out for its innovative approach and variety of initiatives. The ambitious plan committed to by the municipality includes the following (Concept of Implementation CE in Wielun 2017; Deloitte 2018):

- construction of underground containers for separate collection of municipal waste in places where conventional containers cannot be placed

- setting up several dozen (about 30) reverse vending machines for separate collection of PET plastic bottles and aluminium cans, in exchange for which residents may receive discount vouchers for services provided by the municipality, including discounts on water and sewerage charges, cinema or swimming pool tickets, or a pass for free use of paid parking zones

- construction of solar panel shelters over public car parks and covering the roofs of buildings owned by the municipality (schools, gym facilities, community centres, etc.) with photovoltaic panels

- construction of a geothermal heat and power plant, a biomass thermal power plant, and a biogas plant

- replacement of public transport buses with a fleet powered by biogas or electricity from renewable generation in the municipality.

The program is expected to bring benefits at multiple levels-from environmental to economic and societal. The municipalities are to deliver on their commitments by 2020. After 2020, the deliverables will be evaluated in order to select model projects that could be replicated by other municipalities, and the program launched on the total, nationwide scale (Deloitte 2018; Appendix 1 to Resolution of the Management Board of NFWP and WM 2018). In 2019, the National Fund for Environmental Protection and Water Management already announced a new call for proposals for $\mathrm{CE}$ implementation in municipalities, taking into account the experience obtained within the cited CE pilot project.

\subsection{Polish Circular Hotspot}

Polish Circular Hotspot is a public cooperation platform based on networking among partners from various sectors for the purpose of introducing innovative, comprehensive, practical, and scalable solutions in all sectors of the economy. It is not the only circular economy networking platform in Europe. Similar initiatives in the Netherlands, Slovenia, Scotland, and Norway have already been successful for years.

The partners of the Polish Circular Hotspot are represented by local and national governments, universities, and scientists from a wide range of disciplines. They cooperate with various industries, including construction, food, packaging, electronics, plastics, logistics, transport, energy, and textiles. 
The main activities of the partnership include work on:

- strategies and roadmaps

- database of innovations and programs

- new business support models giving local authorities and businesses access to circular economy innovations, databases, and CE programs used in Poland and abroad

- business networking (study visits and B2B matchmaking sessions with the support of the Dutch, Swedish, German, French, and Danish embassies)

- workshops about circular economy and circular procurement for public institutions

- circular cities - support for cities to implement circular economics by identifying problems and helping to create solutions/projects for CE changes in their city

- educational activities-workshops and trainings for anyone interested in the circular economy concept.

One more initiative led by the Polish Circular Hotspot is Polish Circular Economy Week. It is a nationwide social campaign to create awareness and encourage the Polish people to change consumption habits and to make them conscious of the use of resources (Polish Circular Hotspot 2019).

\subsection{Circular Cities Program}

The Circular Cities Program is an initiative implemented jointly by the Polish Circular Hotspot and Metabolic Group with co-financing by the MAVA Foundation. As part of the Circular Cities project, Polish cities are invited to join the national circular cities program, starting with developing practical zero-waste strategies.

The purpose of this program is to help prepare an analysis of the current waste flow in a city and to build a transformation strategy towards circular economy. Through the program, cities build sustainable strategies that change waste policy-reducing waste, but also utilizing upcycling and reuse of raw materials. These jointly developed circular strategies work not only to eliminate negative impacts on the environment but also to achieve financial profits and generate new business opportunities, as well as new professional and training prospects. Throughout the process, the participating cities will have the opportunity to exchange experiences with both national and international partners thanks to cooperation within the network of Polish cities and cities gathered in the Circular cities network (covering Europe and North America).

Joining the Metabolic network creates the opportunity for Polish cities to conduct in-depth analysis of value chains, sectors of the economy, and the flow of raw materials for circularity features. Usually, such analyses are implemented in four stages:

- analysis of the socioeconomic and political situation

- researching the flow of raw materials in the city 
- analysis of the impact of innovation on development and the functioning of the city

- strategy preparation (action plan).

As a result of such analysis, a CE roadmap can be created that identifies the possibilities of implementing circular economy solutions in a particular city, and ultimately facilitates the creation of practical and scalable solutions.

To date, reviews of 15 cities including Amsterdam, Rotterdam, Glasgow, and Barcelona have been carried out. This process proved extremely helpful in bringing about effective implementation of circular solutions for these cities and their surrounding regions (Polish Circular Hotspot: Cities and Regions 2019).

\subsection{Reconomy Coalition}

"Reconomy" - the Coalition for Circular Economy-is an association of companies and institutions involved in the promotion of the concept of a sustainable economy and implementation of the principles of circular economy at every stage of business operations.

As part of its activity, the Reconomy Coalition inspires businesses to undertake innovative actions that bring Poland closer to the circular-economy model. The coalition's activities included, among other things, preparing publications and expert studies on the circular economy, disseminating information demonstrating the profitability of GOZ best practices and business models, creating a Polish knowledge base on circular economy, and co-organizing the Polish Circular Economy Week.

The Coalition's activities contribute to increasing environmental awareness and raising the level of managerial education, as well as providing readymade solutions to build a competitive circular economy in Poland. Enterprises joining the project gain expert support and the opportunity to develop business plans in accordance with the objective of the rational use of resources (Reconomy Coalition 2018).

\section{CE Future Prospects in Poland}

Future prospects for CE development in Poland are dependent on the main achievements related to CE model implementation. Given that, during last three years, there was much activity supporting the $\mathrm{CE}$ transition process, the foundation has been laid for the future development of the CE model in Poland-for scaling up the obtained experience, replicating good practices, and continuing to create favorable conditions for future changes. Such progress could be focused on:

- identification of the exact directions for effective implementation of CE Roadmap activities

- more involvement of a wider part of society in CE implementation 
- increasing the level of public and business awareness regarding the advantages of CE solutions

- setting up dedicated stimulation tools for boosting $\mathrm{CE}$ at all possible levels of implementation

- increasing the level of international cooperation on CE projects

- increasing funding for CE basic research and applied research projects

- broader inclusion of CE in formal and non-formal educational programmes and projects

- developing the potential of CE priority sectors in Poland-bioeconomy, transport, and construction

- further incentivizing $\mathrm{CE}$ aspects in the Polish energy sector in order to increase energy efficiency.

\section{Conclusions}

This study has examined the recent achievements, trends, and future prospects of the Polish CE model of development. Its findings are intended to help CE stakeholders to realize the full potential of $\mathrm{CE}$ to improve competitiveness and to make use of all relevant opportunities for smart and sustainable growth at the national, regional, local, micro, and individual levels.

The research shows that significant CE support activities have been carried out during the past three years, but this is not enough to take advantage of the full potential of the CE model. That is why this research was also focused on identification of future prospects for this new model of economic and social development. One of the key aspects for successful integration of CE ideas in all areas important for sustainable development is the greater involvement of a wider part of society-increasing the level of public and business awareness.

One of the main tasks for authorities is therefore popularization of, and increasing support for, CE through financial and non-financial instruments. Public cooperation platforms have also demonstrated their effectiveness in developing CE stakeholder networking. The main criteria of effectiveness, in this case, included the number of projects, networking development, thematic areas covered by the project, involvement of representatives from the various stakeholders group, the level of project internationalization, and public-private partnership development.

Special attention should be paid to CE priority sectors identified in the Polish economy to increase material and energy efficiency and to develop secondary rawmaterials markets. Lastly, wider CE implementation could be achieved by scaling up pilot projects in Polish municipalities to the level of other municipalities and the largest cities with the Circular Cities Program.

Acknowledgements This project has received funding from the European Union's Horizon 2020 research and innovation program under the Marie Skłodowska-Curie grant agreement no. 665778. The project has also received funding from the National Science Centre, Poland, POLONEZ funding program (project registration number 2015/19/P/HS4/02098). 


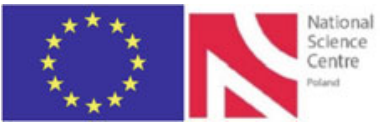

\section{References}

A Circular Economy Strategy for Scotland Report. The Scottish Government 2016. Available https:// circulareconomy.europa.eu/platform/sites/default/files/making_things_last.pdf. Accessed 14 Oct 2019

Alaerts L, Ackera KV, Rousseau S, De Jaeger S, Moragac G, Dewulfc J, De Meesterd S, Van Passele S, Compernolle T, Bachusg K, Vranckenh K, Eyckmansb J (2019) Towards a more direct policy feedback in circular economy monitoring via a societal needs perspective. Resour Conserv Recycl 149:363-371. https://doi.org/10.1016/j.resconrec.2019.06.004

Resolution no B/24/5/2017 of the Management Board of the National Fund for Environmental Protection and Water Management (NFEPandWM), dated May 23rd 2017-in Polish

Resolution no B/23/3/2018 of the Management Board of the National Fund for Environmental Protection and Water Management, dated March 9th 2018-in Polish

Bachorz M (2017) Polish path to circular economy: descriptions of situations and recommendations-in Polish. Available https://igoz.org/raport-polska-droga-do-goz/. Accessed 28 Nov 2019

Baran J, Janik A, Ryszko A, Szafraniec M (2016) Towards a circular economy in Poland: are we moving to a recycling society? Conference: Carpathian Logistics Congress-CLC 2016

Circular Amsterdam: A vision and action agenda for the city and metropolitan area. City government of Amsterdam 2016. Available https://www.circle-economy.com/wp-content/uploads/2016/04/ Circular-Amsterdam-EN-small-210316.pdf. Accessed 14 Nov 2018

Circular Flanders kick-off statement. Vlaanderen Circulair 2017. Available https://circularecon omy.europa.eu/platform/sites/default/files/kick-off_statement_circular_flanders.pdf. Accessed 14 Nov 2019

Closing the loop - an EU action plan for the circular economy. Commission of European Communities. Communication No. 614, 2015

Communication from the Commission - towards a circular economy: a zero waste programme for Europe. Commission of European Communities. Communication No. 398, 2014

Concept for implementation of the circular economy in the Wielun Municipality—in Polish

Extremadura 2030: Strategy for a Green and Circular Economy. Regional Government of Extremadura 2017. Available https://extremadura2030.com/wp-content/uploads/2018/05/estrat egia2030.pdf. Accessed November 14, 2019

France Unveils Circular Economy Roadmap. The French Ministry of Ecological and Solidarity Transition, 2018. Available https://www.ecologique-solidaire.gouv.fr/sites/default/files/FREC\% 20-\%20EN.pdf. Assessed 14 Oct 2019

Germany-German Resource Efficiency Programme (ProgRess II). Federal Ministry for the Environment, Nature Conservation, Building and Nuclear Safety 2016. Available https://www.bmub.bund.de/fileadmin/Daten_BMU/Pools/Broschueren/german_resource_ efficiency_programme_ii_bf.pdf. Accessed 14 Nov 2019

Leading the cycle Finnish road map to a circular economy 2016-2025. Sitra Studies 121, 2016. Available https://media.sitra.fi/2017/02/24032659/Selvityksia121.pdf. Accessed November 28, 2019

Leading the transition: a circular economy action plan for Portugal: 2017-2020. Ministry of Environment of Portugal 2017. Available https://circulareconomy.europa.eu/platform/sites/default/ files/strategy_-_portuguese_action_plan_paec_en_version_3.pdf. Accessed 14 Nov 2019 
London's Circular Economy Route Map. London Waste and Recycling Board 2017. Available https://www.lwarb.gov.uk/wp-content/uploads/2015/04/LWARB-London\%E2\%80\% 99s-CE-route-map_16.6.17a_singlepages_sml.pdf. Accessed 14 Oct 2019

Order No. 33 of the Minister of Development on 24th of June 2016 on the Appointment of the Circular Economy Committee-in Polish

Poland Strategy for Responsible Development for 2020 (with the perspective to 2030). Resolution of the Council of Ministers on 14th February 2017 adopting the Strategy for Responsible Development until 2020 (with the perspective to 2030)—in Polish. Assessed 2 Dec 2019

Polish circular hotspot: cities and regions. Available https://circularhotspot.pl/en/cities-and-regions. Accessed 28 Nov 2019

Polish Circular Hotspot. Available https://circularhotspot.pl/pl/hotspot. Accessed 8 Nov 2019

Promoting Green and Circular Economy in Catalonia: Strategy of the Government of Catalonia. The Government of Catalonia 2015. Available https://circulareconomy.europa.eu/platform/strate gies. Assessed 14 Nov 2019

Programme Régional En Economie Circulaire 2016-2020. Ministry of Housing, Quality of Life, Environment and Energy of Belgium; Minister of the Economy, Employment and Professional training 2016. Available https://document.environnement.brussels/opac_css/elecfile/PROG_1 60308_PREC_DEF_FR. Accessed 14 Oct 2019

Report: Closed loop—open opportunities, Deloitte, 2018. Available https://www2.deloitte.com/pl/ en/pages/zarzadzania-procesami-i-strategiczne/articles/innowacje/raport-zamkniety-obieg-otw arte-mozliwosci.html. Accessed 28 Nov 2019

Resolution No. 88 of the Council of Ministers on 1st July 2016 on the National Plan for Waste Management 2022-in Polish

Roadmap: Transformation towards Circular Economy (in Poland), Appendix to the resolution of the Council of Ministers, September 24, 2019. September 2019. https://www.gov.pl/web/rozwoj/ rada-ministrow-przyjela-projekt-mapy-drogowej-goz. Assessed November 28, 2019-in Polish

Roadmap towards the Circular Economy in Slovenia. Circular Change 2018. Available https:// www.vlada.si/fileadmin/dokumenti/si/projekti/2016/zeleno/ROADMAP_TOWARDS_THE_ CIRCULAR_ECONOMY_IN_SLOVENIA.pdf. Accessed 14 Oct 2019

Reconomy Coalition, 2018. Available https://kampania17celow.pl/wydarzenia/koalicja-reconomy/; https://odpowiedzialnybiznes.pl/dobre-praktyki/reconomy-koalicja-rzecz-gospodarki-obieguzamknietego-stena-recycling/. Accessed 14 Nov 2019

Schulz, C., Hjaltad_ottir, R.E., and Hild, P (2019). Practising circles: Studying institutional change and circular economy practices. Journal of Cleaner Production, 237, 1-9, https://doi.org/10.1016/ j.jclepro.2019.117749

Smol M, Avdiushchenko A, Kulczycka J, Nowaczek A (2018) Public awareness of circular economy in southern Poland: case of the Malopolska region. J Clean Prod 197(1):1035-1045. https://doi. org/10.1016/j.jclepro.2018.06.100

Seroka-Stolka O, Ociepa-Kubicka A (2019) Green logistics and circular economy. Transp Res Procedia 39:471-479. https://doi.org/10.1016/j.trpro.2019.06.049

Towards a Model of Circular Economy for Italy-Overview and Strategic Framework. Ministry for the Environment, Land and Sea Ministry of Economic Development 2017. Available https://circulareconomy.europa.eu/platform/sites/default/files/strategy_-_towards_a_ model_eng_completo.pdf. Accessed 14 Nov 2019

White Paper on the Circular Economy of the Greater Paris. City government of Paris 2016. Available https://api-site.paris.fr/images/77050. Accessed 14 Nov 2019

Woźniak J, Pactwa K (2018) Overview of Polish mining wastes with circular economy model and its comparison with other wastes. Sustainability 10:3994. https://doi.org/10.3390/su10113994

Woźniak E, Twardowski T (2018) The bioeconomy in Poland within the context of the European Union. New Biotechnol 40(A):96-102. https://doi.org/10.1016/j.nbt.2017.06.003 
Open Access This chapter is licensed under the terms of the Creative Commons Attribution 4.0 International License (http://creativecommons.org/licenses/by/4.0/), which permits use, sharing, adaptation, distribution, and reproduction in any medium or format, as long as you give appropriate credit to the original author(s) and the source, provide a link to the Creative Commons license, and indicate if changes were made.

The images or other third party material in this chapter are included in the chapter's Creative Commons license, unless indicated otherwise in a credit line to the material. If material is not included in the chapter's Creative Commons license and your intended use is not permitted by statutory regulation or exceeds the permitted use, you will need to obtain permission directly from the copyright holder.

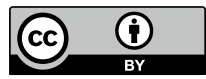

